University of Nebraska - Lincoln

DigitalCommons@University of Nebraska - Lincoln

Publications, Agencies and Staff of the U.S.

Department of Commerce

U.S. Department of Commerce

2007

\title{
Estimating abundance of killer whales in the nearshore waters of the Gulf of Alaska and Aleutian Islands using line-transect sampling
}

\author{
Alexandre N. Zerbini \\ Washington Cooperative Fish and Wildlife Research Unit, School of Aquatic and Fishery Sciences, \\ University of Washington, Box 355020, Seattle, WA \\ Janice M. Waite \\ National Marine Mammal Laboratory, NOAA Fisheries, Alaska Fisheries Science Center \\ John W. Durban \\ National Marine Mammal Laboratory, NOAA Fisheries, Alaska Fisheries Science Center \\ Rick LeDuc \\ Southwest Fisheries Science Center \\ Marilyn E. Dahlheim \\ National Marine Mammal Laboratory, NOAA Fisheries, Alaska Fisheries Science Center \\ See next page for additional authors \\ Follow this and additional works at: https://digitalcommons.unl.edu/usdeptcommercepub \\ Part of the Environmental Sciences Commons
}

Zerbini, Alexandre N.; Waite, Janice M.; Durban, John W.; LeDuc, Rick; Dahlheim, Marilyn E.; and Wade, Paul R., "Estimating abundance of killer whales in the nearshore waters of the Gulf of Alaska and Aleutian Islands using line-transect sampling" (2007). Publications, Agencies and Staff of the U.S. Department of Commerce. 155.

https://digitalcommons.unl.edu/usdeptcommercepub/155

This Article is brought to you for free and open access by the U.S. Department of Commerce at DigitalCommons@University of Nebraska - Lincoln. It has been accepted for inclusion in Publications, Agencies and Staff of the U.S. Department of Commerce by an authorized administrator of DigitalCommons@University of Nebraska - Lincoln. 


\section{Authors}

Alexandre N. Zerbini, Janice M. Waite, John W. Durban, Rick LeDuc, Marilyn E. Dahlheim, and Paul R. Wade 


\title{
Estimating abundance of killer whales in the nearshore waters of the Gulf of Alaska and Aleutian Islands using line-transect sampling
}

\author{
Alexandre N. Zerbini • Janice M. Waite • \\ John W. Durban • Rick LeDuc • Marilyn E. Dahlheim • \\ Paul R. Wade
}

Received: 31 October 2005 / Accepted: 14 April 2006 / Published online: 9 August 2006

(c) Springer-Verlag 2006 This article is a U.S. government work, and is not subject to copyright in the United States.

\begin{abstract}
Killer whale (Orcinus orca Linnaeus, 1758) abundance in the North Pacific is known only for a few populations for which extensive longitudinal data are available, with little quantitative data from more remote regions. Line-transect ship surveys were conducted in July and August of 2001-2003 in coastal waters of the western Gulf of Alaska and the Aleutian Islands. Conventional and Multiple Covariate Distance Sampling methods were used to estimate the abundance of different killer whale ecotypes, which were distinguished based upon morphological and genetic data. Abundance was calculated separately for two data sets that differed in the method by which killer whale group size data were obtained. Initial group size (IGS) data corresponded to estimates of group size at the time
\end{abstract}

Communicated by J.P. Grassle, New Brunswick.

Electronic Supplementary Material Supplementary material is available in the online version of this article at http://dx.doi.org/ $10.1007 / \mathrm{s} 00227-006-0347-8$ and is accessible for authorized users.

A. N. Zerbini $(\bowtie)$

Washington Cooperative Fish and Wildlife Research Unit,

School of Aquatic and Fishery Sciences,

University of Washington, Box 355020 ,

Seattle, WA 98115-5020, USA

e-mail: azerbini@u.washington.edu

A. N. Zerbini · J. M. Waite · J. W. Durban ·

M. E. Dahlheim · P. R. Wade

National Marine Mammal Laboratory,

NOAA Fisheries, Alaska Fisheries Science Center,

7600 Sand Point Way NE, Seattle, WA 98115, USA

R. LeDuc

Southwest Fisheries Science Center,

8604 La Jolla Shores, La Jolla, CA 92037, USA of first sighting, and post-encounter group size (PEGS) corresponded to estimates made after closely approaching sighted groups. 'Resident'-type (fish-eating) killer whales were more abundant than the 'transient'-type (mammal-eating). Abundance estimates of resident killer whales (991 [95\% CI $=379-2,585]$ [IGS] and $1,587[95 \% \mathrm{CI}=608-4,140]$ [PEGS]), were at least four times greater than those of the transient killer whales (200 [95\% CI $=81-488]$ [IGS] and 251 [95\% $\mathrm{CI}=97-644]$ whales $[\mathrm{PEGS}])$. The IGS estimate of abundance is preferred for resident killer whales because the estimate based on PEGS data may show an upward bias. The PEGS estimate of abundance is likely more accurate for transients. Residents were most abundant near Kodiak Island in the northern Gulf of Alaska, around Umnak and Unalaska Islands in the eastern Aleutians, and in Seguam Pass in the central Aleutians. This ecotype was not observed between 156 and $164^{\circ} \mathrm{W}$, south of the Alaska Peninsula. In contrast, transient killer whale sightings were found at higher densities south of the Alaska Peninsula between the Shumagin Islands and the eastern Aleutians. Only two sightings of 'offshore'-type killer whales were recorded during the surveys, one northeast of Unalaska Island and the other south of Kodiak Island. These are the first estimates of abundance of killer whale ecotypes in the Aleutian Islands and Alaska Peninsula area and provide a baseline for quantifying the role of these top predators in their ecosystem.

\section{Introduction}

The killer whale (Orcinus orca) is cosmopolitan in distribution (Dahlheim and Heyning 1998). In the 
northeastern Pacific Ocean, killer whale abundance and population biology has been well documented at longterm study sites in Prince William Sound, southeastern Alaska, British Columbia, and Puget Sound (Bigg et al. 1990; Olesiuk et al. 1990; Matkin et al. 1994; Dahlheim et al. 1997; Ford et al. 2000). These studies have documented three sympatric forms (or ecotypes) of killer whales, named 'residents', 'transients', and 'offshores', which differ in morphology, ecology, behavior, and genetics (Bigg et al. 1990; Baird and Stacey 1988; Hoelzel and Dover 1991; Matkin and Saulitis 1994; BarrettLennard et al. 1996; Ford et al. 1998, 2000; Hoelzel et al. 1998; Baird 2000). Notably, these ecotypes differ markedly in their feeding specializations, with residents being primarily fish-eaters in contrast to transients that feed mainly on marine mammals (Ford et al. 1998; Saulitis et al. 2000; Herman et al. 2005). Relatively few feeding observations have been made for the offshore type, but initial data would suggest that they may also be fish-eaters (Ford et al. 2000; Jones 2006). Patterns of occurrence within localized study areas vary considerably among the ecotypes (Ford et al. 2000). As more data are acquired over greater geographical and temporal scales, it has become apparent that the terms defining these three ecotypes do not fully depict their distribution and movement patterns.

There are very few quantitative data on killer whale abundance in the more remote regions of the far North Pacific, but there is considerable interest in killer whales and their role as apex predators in ecosystems. Predation by transient killer whales has been suggested as a factor in the declines of several marine mammal species in the western Gulf of Alaska, Aleutian Islands, and Bering Sea (Estes et al. 1998; Springer et al. 2003). Additionally, resident killer whales in this area overlap in distribution with extensive commercial fisheries, and depredation on long-line fish catches is commonly reported (Yano and Dahlheim 1995a, b). Evaluating the role of killer whales in the ecosystem requires empirical data on the abundance and distribution of killer whale ecotypes in this area. Although killer whale populations have been well documented for the waters of southeastern Alaska and Prince William Sound (e.g., Dahlheim et al. 1997; Matkin et al. 1999a, b), relatively little data exist in Alaskan waters west of Kodiak Island. Before this study, the only dedicated surveys in this area occurred in 1992 and 1993, when a minimum count of nearly 300 individuals was obtained through photo-identification in an area ranging from the western Gulf of Alaska to the central Aleutian Islands (Dahlheim and Waite 1993; Dahlheim 1997). However, it is unclear how this minimum count related to the total abundance of killer whales in the area, and information on ecotype and stock structure was unavailable.

Line-transect surveys using distance sampling protocols (Buckland et al. 2001) have been used extensively to estimate abundance of cetaceans, including killer whales (e.g., Hammond 1984; Sigurjónsson et al. 1989; Wade and Gerrodette 1993; Barlow 1995; Forney et al. 1995; Branch and Butterworth 2001; Waite et al. 2002). The present study combines distance sampling methods with photographic and genetic data on ecotype identity to estimate abundance and obtain baseline information on distribution of killer whale ecotypes in coastal waters of the western Gulf of Alaska and the Aleutian Islands.

\section{Materials and methods}

Study area, survey design, and field methods

The survey was designed to estimate the abundance of O. orca (Linnaeus, 1758) within the known haulout range of the western stock of Steller sea lions in US waters. This stock is listed as 'endangered', pursuant to the US Endangered Species Act of 1973 [16 United States Code, pp. 1,531-1,543 (Supp. IV 1974)] as amended. In response to the possible impact of predation on Steller sea lions by killer whales (NRC 2003), the highest priority of the survey was to estimate the abundance of transient whales. In the summer, Steller sea lions are thought to forage primarily in relatively close proximity to their rookeries and haulouts (Merrick and Loughlin 1997; Loughlin et al. 2003). Therefore, the survey was designed to include a $55-\mathrm{km}$ area around Steller sea lion rookeries and major haulouts. The surveys were extended in some areas where rookeries and haulouts occur on small islands that are up to $20 \mathrm{~km}$ from the main coastline or the major islands (Fig. 1). The eastern boundary of the study area was located at the eastern border of the western stock of Steller sea lions, along the coastline of the Kenai Peninsula $\left(\sim 60^{\circ} \mathrm{N}, 150^{\circ} \mathrm{W}\right)$. The western boundary of the study area was determined by logistical limitations, and was located at the western side of Seguam Pass $\left(\sim 56^{\circ} \mathrm{N}, 172^{\circ} \mathrm{W}\right)$ in the central Aleutian Islands in 2001, and was moved further west to Amchitka Pass $\left(\sim 52^{\circ} \mathrm{N}, 178^{\circ} \mathrm{W}\right)$ in 2002 and 2003.

Three surveys were conducted each summer (July and August) between 2001 and 2003 (Fig. 1). The survey track followed a saw-tooth (zig-zag) pattern inside a rectangle (hereafter called block). The offshore boundary of each block was drawn parallel to the major axis of the coastline. Multiple blocks were 


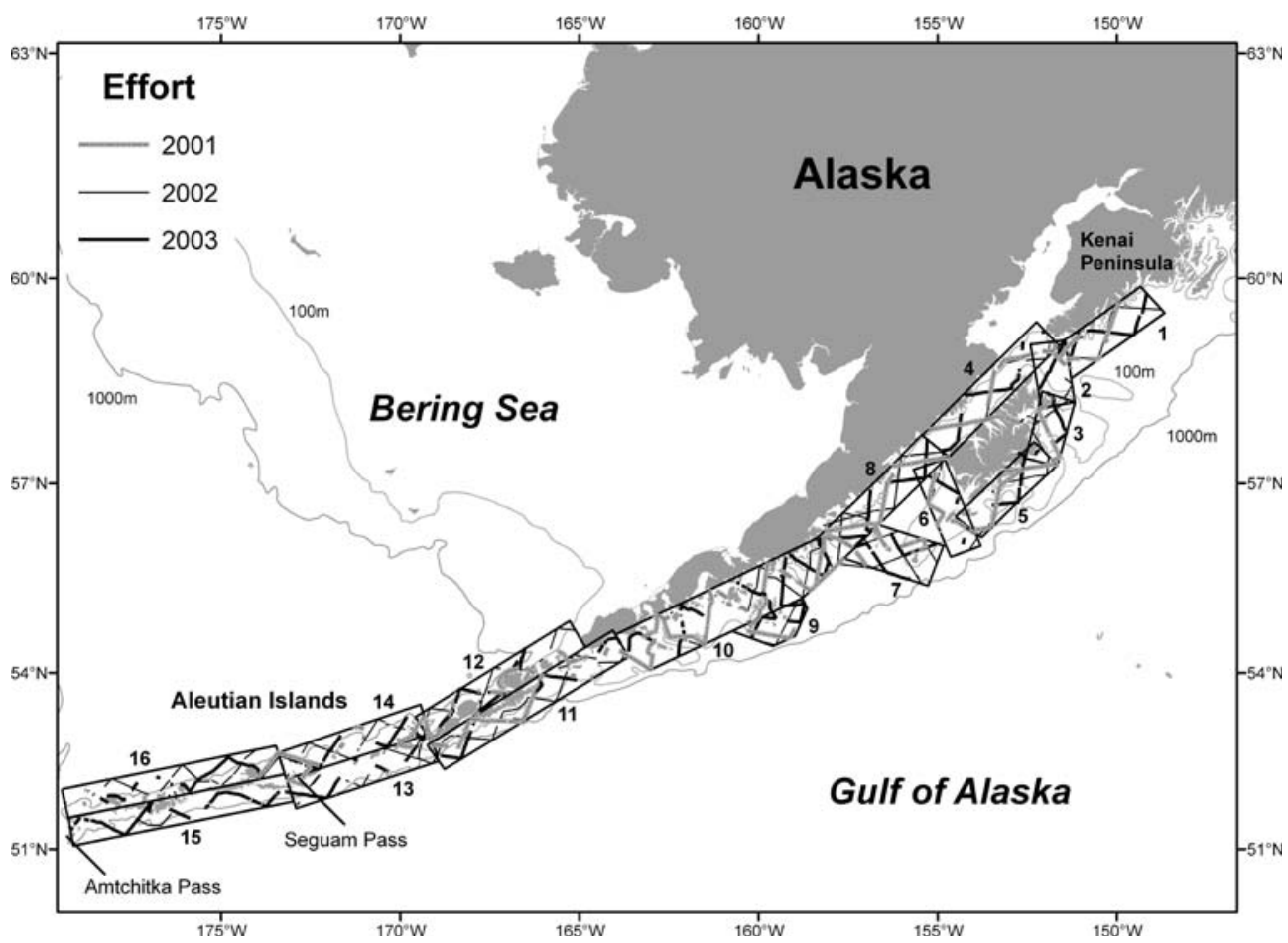

Fig. 1 Map of completed transect legs and blocks for line-transect surveys in central Alaska coastal waters

established, with each block designated as a stratum in a stratified survey design (Table 1, Fig. 1). Breakpoints for establishing the ends of the strata were established at various locations to accommodate changes in the orientation of the coastline, the need to extend the study area further offshore to include various island groups, and to align with major areas already used for examining the trends in abundance of the western

Table 1 Survey strata, area, and effort

\begin{tabular}{|c|c|c|c|c|c|}
\hline \multirow[t]{2}{*}{ Stratum } & \multirow[t]{2}{*}{ Area $\left(\mathrm{km}^{2}\right)$} & \multicolumn{4}{|c|}{ Effort (km) } \\
\hline & & 2001 & 2002 & 2003 & Total \\
\hline 1 & 9,060 & 114.2 & 193.3 & 201.3 & 508.8 \\
\hline 2 & 3,910 & 28.5 & 42.5 & 88.7 & 159.7 \\
\hline 3 & 4,926 & 116.6 & 125.5 & 97.5 & 339.6 \\
\hline 4 & 13,190 & 222.7 & 159.9 & 202.4 & 585.0 \\
\hline 5 & 9,757 & 189.6 & 132.2 & 136.1 & 457.9 \\
\hline 6 & 7,809 & 130.5 & 42.1 & 63.6 & 236.2 \\
\hline 7 & 10,250 & 95.2 & 231.5 & 187.5 & 514.2 \\
\hline 8 & 14,464 & 274.4 & 315.6 & 278.6 & 868.7 \\
\hline 9 & 5,487 & 98.9 & 142.9 & 124.5 & 366.3 \\
\hline 10 & 28,827 & 493.9 & 514.6 & 448.7 & $1,457.2$ \\
\hline 11 & 14,919 & 256.1 & 278.0 & 225.8 & 759.9 \\
\hline 12 & 20,214 & 84.1 & 388.2 & 306.5 & 778.9 \\
\hline 13 & 15,647 & 44.6 & 270.4 & 185.1 & 500.0 \\
\hline 14 & 15,726 & 182.7 & 235.8 & 135.3 & 553.8 \\
\hline 15 & 22,161 & - & 320.5 & 219.7 & 540.2 \\
\hline 16 & 21,266 & - & 55.4 & 371.8 & 427.2 \\
\hline Total & 217,613 & $2,332.0$ & $3,448.5$ & $3,273.2$ & $9,053.6$ \\
\hline
\end{tabular}

stock of Steller sea lions. Specifically, the four Steller sea lion areas of the Central Gulf of Alaska, Western Gulf of Alaska, Eastern Aleutian Islands, and Central Aleutian Islands as far west as Seguam Pass were surveyed. Fourteen blocks were designated in 2001 and 16 were designated in 2002 and 2003 to include the extension of the study area to the west in those years. The total area surveyed was $177,656 \mathrm{~km}^{2}$ in 2001 and $221,083 \mathrm{~km}^{2}$ in 2002 and 2003 . The proposed effort was 4,250 km (2001), 5,470 km (2002), and 5,400 km (2003). Effort per unit of area was kept constant across all the proposed blocks. This provides the greatest flexibility in analysis, as a constant search effort allows pooling for analysis if desired, while still allowing for abundance and density in individual blocks to be considered. A random number generator was used to position the first transect leg in each block. This survey design ensures that the track-lines provide equal coverage probability of the study area. When sighting conditions were good, the observer teams maintained marine mammal watches while transiting between transect legs. These off-effort legs were designated transit legs. Although this effort was not used for estimating the density, the line-transect protocol was maintained because perpendicular distance information could potentially be included in estimating the detection function for line-transect analysis, and sightings contributed to distribution information. 
Line-transect surveys were carried out on board two different vessels: the $F / V$ Aleutian Mariner in 2001 and the M/V Coastal Pilot in 2002 and 2003. The former was $38 \mathrm{~m}$ long and had an observation height of $5.5 \mathrm{~m}$ above the water while the latter was $53 \mathrm{~m}$ long and had an observation height of $9.2 \mathrm{~m}$. Six observers rotated through three observation positions (starboard, data recorder, and port). A full observation period lasted $2 \mathrm{~h}$ (40 min in each position) and was followed by a $2-\mathrm{h}$ rest period. The observer rotation order was randomized. Starboard and port observers were stationed on the outside observation platform and the data recorder was positioned inside the bridge at a computer station. Starboard and port observers used $7 \times 50$ Fujinon binoculars with reticules to search from $10^{\circ}$ on the other observer's side of the ship's bow to $90^{\circ}$ on their side of the ship. The data recorder searched the track-line while scanning through the viewing areas of the two primary observers. Observers and the data recorder had an angle board to determine horizontal angle from the track-line to observed cetacean groups. If the data recorder saw a sighting first, he or she would alert one of the observers of a sighting and receive the necessary information from the primary observer (described below). When a sighting was made, the observer alerted the recorder to incoming information and determined the horizontal angle and number of reticules from the horizon to the sighting when it was first seen. Additional information collected was sighting cue, course and speed, species identity, and best, low, and high estimates of group size. The computer program WINCRUZ ${ }^{1}$ was used to record all sighting and environmental data (e.g., cloud cover, wind strength and direction, and sea conditions). The computer was interfaced to a portable GPS to gather positional and navigational information.

Searching effort was continuously maintained from about $30 \mathrm{~min}$ after sunrise to nearly $30 \mathrm{~min}$ before sunset, unless weather and visibility conditions (rain and fog) were poor or sea-state was above Beaufort 5 . Under unacceptable weather conditions, the recorder stayed on watch on the bridge to record off-effort sightings and environmental data.

When killer whales were sighted, the line-transect survey effort was temporarily suspended to allow closer approaches to the whales and a small boat (5-6 m) was launched when weather conditions permitted. Photographs of the killer whales' dorsal fins and adjacent saddle patch pigmentation were obtained using $35 \mathrm{~mm}$

\footnotetext{
${ }^{1}$ Available from Robert Holland (Robert.Holland@noaa.gov) at the Southwest Fisheries Science Center (SWFSC), La Jolla, CA, USA.
}

SLR cameras shooting high-speed black and white film. Tissue samples were collected using remote biopsy techniques (Barrett-Lennard et al. 1996). All of this information was used to determine the ecotype of different killer whale groups encountered.

This study differed from previous killer whale linetransect surveys in that two estimates of group size were obtained. Once a sighting was made, observers went off-effort and the ship approached the group to collect biopsy, acoustic, and photo-identification data. During the approach the observers and the data recorder collected independent estimates of the number of whales in the group. These estimates were then averaged to produce an 'initial group size' (IGS) estimate. A second estimate was obtained after time was spent observing the whales while conducting photoidentification and biopsy data collection. This is referred to as the 'post-encounter group size' (PEGS) estimate. Separate estimates of abundance were calculated for the two group size estimate categories.

\section{Ecotype determination}

The determination of ecotype was made post-cruise. Photographs from each encounter were examined independently by the two experienced biologists (J.W. and M.D.) and ecotype assignment was based on the examination of morphological differences of the dorsal fin shape and saddle patch pigmentation, previously identified from long-term studies as diagnostic features to identify killer whale ecotypes (Baird and Stacey 1988; Ford et al. 2000). All photographs of whales collected during an encounter were examined. Typically, some portion of a group showed obvious morphological characteristics that distinguished the ecotype, and the whole group could be classified based on the presence of those characteristics. However, some groups either were not photographed or the photographs were of insufficient quality to determine ecotype. These groups were classified as having an 'unknown' ecotype.

Where possible, photographic determinations of ecotype were confirmed for groups that had been biopsy sampled and genetically assigned to ecotype based on mitochondrial DNA (mtDNA) sequence variation. The entire mtDNA control region was amplified in two overlapping segments from extracted genomic DNA (Qiagen DNeasy \#69506, Qiagen DNeasy, Valencia, CA, USA). The $5^{\prime}$ fragment was amplified using primers H16498 (5'-cctgaagtaagaaccagatg-3'; Rosel et al. 1994) and L15812 [5'-cctccctaagactcaaggaag-3'; developed at the Southwest Fisheries Science Center (SWFSC), La Jolla, CA, USA]. The $3^{\prime}$ fragment was amplified using DL3C (5'-gtgaaaccagcaacc cgc-3') 
and 12SC ( $5^{\prime}$-aaggctgggaccaaacctt- $\left.3^{\prime}\right)$, both developed at the SWFSC. The same primers were used to independently sequence both strands of each amplified DNA product for each specimen as mutual controls using standard protocols on the Applied Biosystems Inc. (Foster City, CA, USA) model 3100 sequencer. Sequences were aligned using Sequencher software, version 4.1 (Gene Codes, Ann Arbor, MI, USA). Fixed mtDNA sequence differences have been found between known killer whale ecotypes in long-term study sites in the North Pacific Ocean (Hoelzel et al. 1998, 2002; Barrett-Lennard 2000). Assignment to ecotype was based on sequence matches with killer whales of known ecotype based on multiple lines of evidence (genetics and photo-id). Additionally, new (i.e., previously unreported) sequences were assigned to ecotype based on mtDNA sequence similarity when aligned with previously published killer whale haplotypes. Haplotype sequences are available from GenBank (accession nos. DQ399074-DQ399082).

In addition, because groups only associate with other groups within their ecotype (Ford et al. 2000), it was possible to use photo-identification data on between-group associations to verify or even classify a group's ecotype based on the repeated association of individual whales across multiple photo-documented groups. For instance, if a group confirmed as transient based on its mtDNA sequence was seen associating with another group, then the second group was also classified as transient based on the association.

Estimation of detection probability, model

specification, and abundance estimation

Detection probability was estimated by modeling ungrouped and untruncated perpendicular distance data pooled across ecotypes and survey blocks. Both Conventional Distance Sampling (CDS) and Multiple Covariate Distance Sampling (MCDS) approaches were used (Buckland et al. 2001, 2004; Marques and Buckland 2003). MCDS differs from CDS because it allows for the inclusion of environmental covariates in the estimation of detection probability $(P)$. Half normal and hazard rate functions were used to model $P$, and covariates were incorporated via the scale parameter as described by Innes et al. (2002) and Marques and Buckland (2003). Models were proposed to investigate the effects of covariates in the probability of detecting killer whale groups, but the small sample of on-effort sightings precluded the use of more than one covariate. Even though variables such as ship height and sea-state may affect $P$, an exploratory analysis indicated that group size was the most important covariate given the substantial differences in this variable for transient vs. resident and offshore killer whales. Therefore, only group size was used as a covariate in this study, resulting in four proposed models (half normal and hazard rate functions with and without a group size covariate). In this study, the probability of detecting whales on the track-line $(g[0])$ was assumed to be unity.

Ecotype-specific abundance and variance estimates were obtained for each proposed model to fit perpendicular distance data as described by Innes et al. (2002) and Marques and Buckland (2003). Models were ranked according to the Akaike Information Criterion, which provides a measure of model fit with a penalty term for the number of parameters in the model (Akaike 1973). Unconditional model selection variance was incorporated in the estimates through model averaging (Burnham and Anderson 2002), and log-normal 95\% confidence intervals (Buckland et al. 2001) were calculated for the model-averaged parameter estimates.

\section{Results}

A total of $9,053.6 \mathrm{~km}$ was surveyed on effort in all years, approximately $60 \%$ of the proposed track-line (Table 1). Fifty-nine (39 on- and 20 off-effort) sightings of $O$. orca were recorded in the 3 years (Table 2). Ecotypes were assigned for 55 sightings (93\%), based on morphological analyses from photographs. No assignment disagreement occurred between independently working biologists. Ecotype determination was confirmed for 32 sightings (54\%) (Table 2) using mtDNA haplotype sequences. Groups with the previously recognized haplotypes of GAT1, GAT2, and AT1 were assigned a molecular ecotype of transient, groups with the known haplotypes SR or NR were assigned a molecular ecotype of resident, and groups with the haplotype OFF were assigned a molecular ecotype of offshore (according to Hoelzel et al. 1998, 2002; Barrett-Lennard 2000). Three novel mtDNA haplotypes were detected, and assignments of these individuals to ecotype were based on greatest similarity of the novel haplotypes to previously recorded haplotypes. Therefore, haplotypes NT1 and NT2 were considered as transient haplotypes based on a sequence difference of only two and one base pairs, respectively, from the GAT1 haplotype. Similarly, the NEWR haplotype was only a single base pair different from the SR haplotype.

Ecotype assignment was consistent for all those records where both photo-identification and genetic data were available (Table 2). The two sightings with the new transient mtDNA haplotypes were also 
Table 2 Sightings in western Alaska in July and August 2001-2003

\begin{tabular}{|c|c|c|c|c|c|c|c|c|c|}
\hline Record & Date & Latitude & Longitude & $\begin{array}{l}\text { Photo } \\
\text { ecotype }\end{array}$ & $\begin{array}{l}\text { Molecular } \\
\text { ecotype }\end{array}$ & $\begin{array}{l}\text { \# Biopsy } \\
\text { samples }\end{array}$ & $\begin{array}{l}\text { Initial } \\
\text { group size }\end{array}$ & $\begin{array}{l}\text { Post-encounter } \\
\text { group size }\end{array}$ & $\begin{array}{l}\text { On/off } \\
\text { effort }\end{array}$ \\
\hline 1 & 20-Jul-2001 & $59^{\circ} 00^{\prime} \mathrm{N}$ & $150^{\circ} 24 \mathrm{~W}$ & $\mathrm{R}$ & & & - & 25 & Off \\
\hline 2 & 21-Jul-2001 & $58^{\circ} 48^{\prime} \mathrm{N}$ & $151^{\circ} 36^{\prime} \mathrm{W}$ & $\mathrm{T}$ & $\mathrm{T}$ & 1 & 4 & 4 & On \\
\hline 3 & 24-Jul-2001 & $57^{\circ} 12^{\prime} \mathrm{N}$ & $152^{\circ} 30^{\prime} \mathrm{W}$ & $\mathrm{R}$ & & & 2 & 25 & On \\
\hline 4 & 25-Jul-2001 & $56^{\circ} 18^{\prime} \mathrm{N}$ & $154^{\circ} 00^{\prime} \mathrm{W}$ & $\mathrm{R}$ & $\mathrm{R}$ & 4 & 90 & 89 & On \\
\hline 5 & 26-Jul-2001 & $56^{\circ} 24^{\prime} \mathrm{N}$ & $154^{\circ} 36^{\prime} \mathrm{W}$ & $\mathrm{O}$ & & & 40 & 40 & On \\
\hline 6 & 31-Jul-2001 & $55^{\circ} 36^{\prime} \mathrm{N}$ & $159^{\circ} 30^{\prime} \mathrm{W}$ & $\mathrm{T}$ & & & - & 7 & Off \\
\hline 7 & 1-Aug-2001 & $54^{\circ} 42^{\prime} \mathrm{N}$ & $158^{\circ} 60^{\prime} \mathrm{W}$ & $\mathrm{T}$ & $\mathrm{T}$ & 1 & 3 & 3 & On \\
\hline 8 & 3-Aug-2001 & $54^{\circ} 18^{\prime} \mathrm{N}$ & $164^{\circ} 36^{\prime} \mathrm{W}$ & $\mathrm{T}$ & $\mathrm{T}$ & 1 & 2 & 3 & On \\
\hline 9 & 4-Aug-2001 & $54^{\circ} 00^{\prime} \mathrm{N}$ & $166^{\circ} 54^{\prime} \mathrm{W}$ & $\mathrm{R}$ & & & 15 & 17 & On \\
\hline 10 & 5-Aug-2001 & $54^{\circ} 00^{\prime} \mathrm{N}$ & $167^{\circ} 06^{\prime} \mathrm{W}$ & $\mathrm{R}$ & & & 5 & 10 & On \\
\hline 11 & 11-Aug-2001 & $54^{\circ} 36^{\prime} \mathrm{N}$ & $162^{\circ} 54^{\prime} \mathrm{W}$ & $\mathrm{T}$ & & & 3 & 3 & On \\
\hline 12 & 11-Aug-2001 & $54^{\circ} 18^{\prime} \mathrm{N}$ & $163^{\circ} 00^{\prime} \mathrm{W}$ & $\mathrm{U}$ & & & 4 & 4 & On \\
\hline 13 & 14-Aug-2001 & $53^{\circ} 30^{\prime} \mathrm{N}$ & $168^{\circ} 36^{\prime} \mathrm{W}$ & $\mathrm{R}$ & $\mathrm{R}$ & 1 & 10 & 10 & On \\
\hline 14 & 14-Aug-2001 & $53^{\circ} 06^{\prime} \mathrm{N}$ & $168^{\circ} 54^{\prime} \mathrm{W}$ & $\mathrm{T}$ & & & - & 2 & Off \\
\hline 15 & 17-Aug-2001 & $52^{\circ} 12^{\prime} \mathrm{N}$ & $173^{\circ} 00^{\prime} \mathrm{W}$ & $\mathrm{T}$ & $\mathrm{T}$ & 1 & 3 & 3 & On \\
\hline 16 & 17-Aug-2001 & $52^{\circ} 18^{\prime} \mathrm{N}$ & $172^{\circ} 54^{\prime} \mathrm{W}$ & $\mathrm{R}$ & $\mathrm{R}$ & 2 & 50 & 50 & On \\
\hline 17 & 24-Aug-2001 & $53^{\circ} 00^{\prime} \mathrm{N}$ & $168^{\circ} 12^{\prime} \mathrm{W}$ & $\mathrm{R}$ & $\mathrm{R}$ & 1 & - & 38 & Off \\
\hline 18 & 25-Aug-2001 & $53^{\circ} 12^{\prime} \mathrm{N}$ & $167^{\circ} 00^{\prime} \mathrm{W}$ & $\mathrm{R}$ & $\mathrm{R}$ & 2 & 15 & 15 & On \\
\hline 19 & 5-Aug-2001 & $54^{\circ} 06^{\prime} \mathrm{N}$ & $166^{\circ} 36^{\prime} \mathrm{W}$ & $\mathrm{R}$ & $\mathrm{R}$ & 1 & - & 10 & Off \\
\hline 20 & 12-Jul-2002 & $54^{\circ} 06^{\prime} \mathrm{N}$ & $166^{\circ} 48^{\prime} \mathrm{W}$ & $\mathrm{U}$ & & & 3 & 3 & On \\
\hline 21 & 12-Jul-2002 & $54^{\circ} 06^{\prime} \mathrm{N}$ & $166^{\circ} 54^{\prime} \mathrm{W}$ & $\mathrm{R}$ & & & 11 & 12 & On \\
\hline 22 & 13-Jul-2002 & $54^{\circ} 00^{\prime} \mathrm{N}$ & $166^{\circ} 18^{\prime} \mathrm{W}$ & $\mathrm{R}$ & $\mathrm{R}$ & 1 & - & 14 & Off \\
\hline 23 & 17-Jul-2002 & $52^{\circ} 42^{\prime} \mathrm{N}$ & $169^{\circ} 36^{\prime} \mathrm{W}$ & $\mathrm{R}$ & $\mathrm{R}$ & 1 & 35 & 46 & On \\
\hline 24 & 18-Jul-2002 & $52^{\circ} 06^{\prime} \mathrm{N}$ & $172^{\circ} 24^{\prime} \mathrm{W}$ & $\mathrm{R}$ & $\mathrm{R}$ & 1 & 6 & 8 & On \\
\hline 25 & 25-Jul-2002 & $52^{\circ} 18^{\prime} \mathrm{N}$ & $172^{\circ} 18^{\prime} \mathrm{W}$ & $\mathrm{T}$ & & & 6 & 13 & On \\
\hline 26 & 27-Jul-2002 & $52^{\circ} 54^{\prime} \mathrm{N}$ & $169^{\circ} 24^{\prime} \mathrm{W}$ & $\mathrm{R}$ & & & 5 & 5 & On \\
\hline 27 & 28-Jul-2002 & $52^{\circ} 42^{\prime} \mathrm{N}$ & $168^{\circ} 54^{\prime} \mathrm{W}$ & $\mathrm{T}$ & $\mathrm{T}$ & 2 & 5 & 5 & On \\
\hline 28 & 29-Jul-2002 & $53^{\circ} 30^{\prime} \mathrm{N}$ & $165^{\circ} 42^{\prime} \mathrm{W}$ & $\mathrm{R}$ & & & 15 & 22 & On \\
\hline 29 & 1-Aug-2002 & $54^{\circ} 12^{\prime} \mathrm{N}$ & $164^{\circ} 30^{\prime} \mathrm{W}$ & $\mathrm{R}$ & $\mathrm{R}$ & 1 & 8 & 39 & On \\
\hline 30 & 13-Aug-2002 & $57^{\circ} 24^{\prime} \mathrm{N}$ & $155^{\circ} 48^{\prime} \mathrm{W}$ & $\mathrm{R}$ & & & 15 & 24 & On \\
\hline 31 & 15-Aug-2002 & $57^{\circ} 06^{\prime} \mathrm{N}$ & $152^{\circ} 12^{\prime} \mathrm{W}$ & $\mathrm{R}$ & & & 5 & 9 & On \\
\hline 32 & 16-Aug-2002 & $58^{\circ} 00^{\prime} \mathrm{N}$ & $152^{\circ} 00^{\prime} \mathrm{W}$ & $\mathrm{R}$ & $\mathrm{R}$ & 1 & 33 & 62 & On \\
\hline 33 & 19-Aug-2002 & $58^{\circ} 48^{\prime} \mathrm{N}$ & $152^{\circ} 30^{\prime} \mathrm{W}$ & $\mathrm{R}$ & & & 7 & 8 & On \\
\hline 34 & 20-Aug-2002 & $58^{\circ} 06^{\prime} \mathrm{N}$ & $153^{\circ} 36^{\prime} \mathrm{W}$ & $\mathrm{R}$ & $\mathrm{R}$ & 1 & - & 22 & Off \\
\hline 35 & 29-Jul-2002 & $53^{\circ} 30^{\prime} \mathrm{N}$ & $165^{\circ} 42^{\prime} \mathrm{W}$ & $\mathrm{T}$ & & & - & 5 & Off \\
\hline 36 & 3-Jul-2003 & $54^{\circ} 00^{\prime} \mathrm{N}$ & $166^{\circ} 24^{\prime} \mathrm{W}$ & $\mathrm{O}$ & $\mathrm{O}$ & 1 & - & 60 & Off \\
\hline 37 & 3-Jul-2003 & $54^{\circ} 06^{\prime} \mathrm{N}$ & $166^{\circ} 12^{\prime} \mathrm{W}$ & $\mathrm{U}$ & & & 15 & - & Off \\
\hline 38 & 5-Jul-2003 & $54^{\circ} 18^{\prime} \mathrm{N}$ & $164^{\circ} 30^{\prime} \mathrm{W}$ & $\mathrm{T}$ & & & 3 & 3 & On \\
\hline 39 & 6-Jul-2003 & $53^{\circ} 12^{\prime} \mathrm{N}$ & $166^{\circ} 54^{\prime} \mathrm{W}$ & $\mathrm{R}$ & $\mathrm{R}$ & 1 & - & 18 & Off \\
\hline 40 & 7-Jul-2003 & $53^{\circ} 42^{\prime} \mathrm{N}$ & $167^{\circ} 30^{\prime} \mathrm{W}$ & $\mathrm{U}$ & & & 3 & 3 & On \\
\hline 41 & 7-Jul-2003 & $53^{\circ} 30^{\prime} \mathrm{N}$ & $168^{\circ} 24^{\prime} \mathrm{W}$ & $\mathrm{T}$ & $\mathrm{T}$ & 4 & 6 & 6 & On \\
\hline 42 & 7-Jul-2003 & $53^{\circ} 36^{\prime} \mathrm{N}$ & $168^{\circ} 12^{\prime} \mathrm{W}$ & $\mathrm{R}$ & $\mathrm{R}$ & 1 & - & 5 & Off \\
\hline 43 & 7-Jul-2003 & $53^{\circ} 36^{\prime} \mathrm{N}$ & $168^{\circ} 18^{\prime} \mathrm{W}$ & $\mathrm{R}$ & & & - & 12 & Off \\
\hline 44 & 10-Jul-2003 & $52^{\circ} 30^{\prime} \mathrm{N}$ & $172^{\circ} 54^{\prime} \mathrm{W}$ & $\mathrm{R}$ & $\mathrm{R}$ & 2 & - & 6 & Off \\
\hline 45 & 10-Jul-2003 & $52^{\circ} 18^{\prime} \mathrm{N}$ & $173^{\circ} 06^{\prime} \mathrm{W}$ & $\mathrm{R}$ & $\mathrm{R}$ & 2 & - & 20 & Off \\
\hline 46 & 11-Jul-2003 & $52^{\circ} 36^{\prime} \mathrm{N}$ & $173^{\circ} 12^{\prime} \mathrm{W}$ & $\mathrm{R}$ & $\mathrm{R}$ & 1 & - & 8 & Off \\
\hline 47 & 14-Jul-2003 & $51^{\circ} 24^{\prime} \mathrm{N}$ & $179^{\circ} 12^{\prime} \mathrm{W}$ & $\mathrm{R}$ & & & 14 & 15 & On \\
\hline 48 & 14-Jul-2003 & $51^{\circ} 24^{\prime} \mathrm{N}$ & $179^{\circ} 06^{\prime} \mathrm{W}$ & $\mathrm{T}$ & $\mathrm{T}$ & 1 & - & 5 & Off \\
\hline 49 & 15-Jul-2003 & $51^{\circ} 36^{\prime} \mathrm{N}$ & $177^{\circ} 00^{\prime} \mathrm{W}$ & $\mathrm{R}$ & $\mathrm{R}$ & 1 & 20 & 21 & On \\
\hline 50 & 19-Jul-2003 & $52^{\circ} 54^{\prime} \mathrm{N}$ & $169^{\circ} 30^{\prime} \mathrm{W}$ & $\mathrm{R}$ & $\mathrm{R}$ & 1 & - & 22 & Off \\
\hline 51 & 21-Jul-2003 & $54^{\circ} 12^{\prime} \mathrm{N}$ & $166^{\circ} 42^{\prime} \mathrm{W}$ & $\mathrm{R}$ & $\mathrm{R}$ & 2 & - & 18 & Off \\
\hline 52 & 21-Jul-2003 & $54^{\circ} 12^{\prime} \mathrm{N}$ & $166^{\circ} 42^{\prime} \mathrm{W}$ & $\mathrm{R}$ & $\mathrm{R}$ & 4 & - & 50 & Off \\
\hline 53 & 23-Jul-2003 & $54^{\circ} 24^{\prime} \mathrm{N}$ & $166^{\circ} 30^{\prime} \mathrm{W}$ & $\mathrm{R}$ & $\mathrm{R}$ & 1 & 6 & 14 & On \\
\hline 54 & 28-Jul-2003 & $55^{\circ} 00^{\prime} \mathrm{N}$ & $160^{\circ} 54^{\prime} \mathrm{W}$ & $\mathrm{T}$ & & & - & 2 & Off \\
\hline 55 & 1-Aug-2003 & $55^{\circ} 30^{\prime} \mathrm{N}$ & $155^{\circ} 42^{\prime} \mathrm{W}$ & $\mathrm{R}$ & & & 2 & 6 & On \\
\hline 56 & 1-Aug-2003 & $55^{\circ} 36^{\prime} \mathrm{N}$ & $155^{\circ} 54^{\prime} \mathrm{W}$ & $\mathrm{R}$ & & & 4 & 4 & On \\
\hline 57 & 6-Aug-2003 & $58^{\circ} 24^{\prime} \mathrm{N}$ & $152^{\circ} 00^{\prime} \mathrm{W}$ & $\mathrm{R}$ & $\mathrm{R}$ & 4 & 8 & 24 & On \\
\hline 58 & 7-Aug-2003 & $59^{\circ} 00^{\prime} \mathrm{N}$ & $151^{\circ} 30^{\prime} \mathrm{W}$ & $\mathrm{R}$ & $\mathrm{R}$ & 2 & 12 & 22 & On \\
\hline 59 & 10-Aug-2003 & $58^{\circ} 42^{\prime} \mathrm{N}$ & $152^{\circ} 42^{\prime} \mathrm{W}$ & $\mathrm{R}$ & & & 8 & 22 & On \\
\hline
\end{tabular}


assigned to the transient ecotype by the photographic analysis, providing further evidence of their ecotype. For the one sighting with the NEWR haplotype, the photographic analysis supported the resident determination, and a second whale with the SR haplotype was sampled from the same sighting, confirming that these were resident-type whales. For three sightings (two transient and one resident) from which no biopsy samples were obtained, ecotypes were further confirmed by association with whales for which a biopsy sample had been obtained in sightings during other surveys.

Resident killer whales were seen near Kodiak Island from $150^{\circ}$ to $156^{\circ} \mathrm{W}$ and west of Unimak Island $\left(\sim 164^{\circ} \mathrm{W}\right)$ (Fig. 2$)$. The area near the Shumagin Islands, south of the Alaska Peninsula, shows a clear absence of records of this ecotype. Transient killer whales were observed east of Kodiak Island and west of $159^{\circ} \mathrm{W}$ (Fig. 2). In contrast to residents, most sightings of transients were observed between the Shumagin Islands and Samalga Pass. Only two offshore killer whale groups were recorded during this study (Fig. 2), one south of Kodiak Island and another north of Unalaska Island. Average group size was greater for offshore and resident than for transient killer whales. Mean IGS, available for on-effort sightings only, were 40 (no SD, $n=1), 16(\mathrm{SD}=19.1, n=25)$, and 3.9 ( $\mathrm{SD}=1.5, n=9)$ for offshore, resident, and transient ecotypes, respectively. PEGS averages were 50 $(\mathrm{SD}=14.1, n=2), 21.7 \quad(\mathrm{SD}=17.7, n=35)$, and 4.6 $(\mathrm{SD}=2.9, n=14)$.

Model-parameter estimates and model-specific estimates of abundance are presented in Table 3. Models with group size covariates ranked better than conventional (CDS) models both when IGS and PEGS were used to estimate the detection probability. Yet, CDS models were moderately supported by the data. Detection functions are illustrated in Appendix 1. The total abundance, pooled across ecotypes, was 1,228 $(\mathrm{CV}=0.45,95 \% \mathrm{CI}=529-2,849)$ and $1,866(\mathrm{CV}=0.46$, $95 \%$ CI $=790-4,403)$ when IGS and PEGS data were used, respectively.

Higher densities of resident whales were estimated for the western side of Kodiak Island (Blocks 2-5, Table 4), where the average density was estimated at 0.010 whales $\mathrm{km}^{-2}$ for IGS and 0.018 whales $\mathrm{km}^{-2}$ for PEGS. Density of residents was also relatively high around Unalaska Island, ranging from 0.009 to 0.015 whales $\mathrm{km}^{-2}$ for IGS and PEGS, respectively (Blocks 11-12, Table 4). The overall estimated density of residents was 0.0046 (IGS) and 0.0073 whales km $\mathrm{km}^{-2}$ (PEGS) and total abundance was estimated at 991 and 1,587 whales, respectively (Table 4).

Estimated densities of transient killer whales were higher in the region of the Shumagin Islands, Unimak

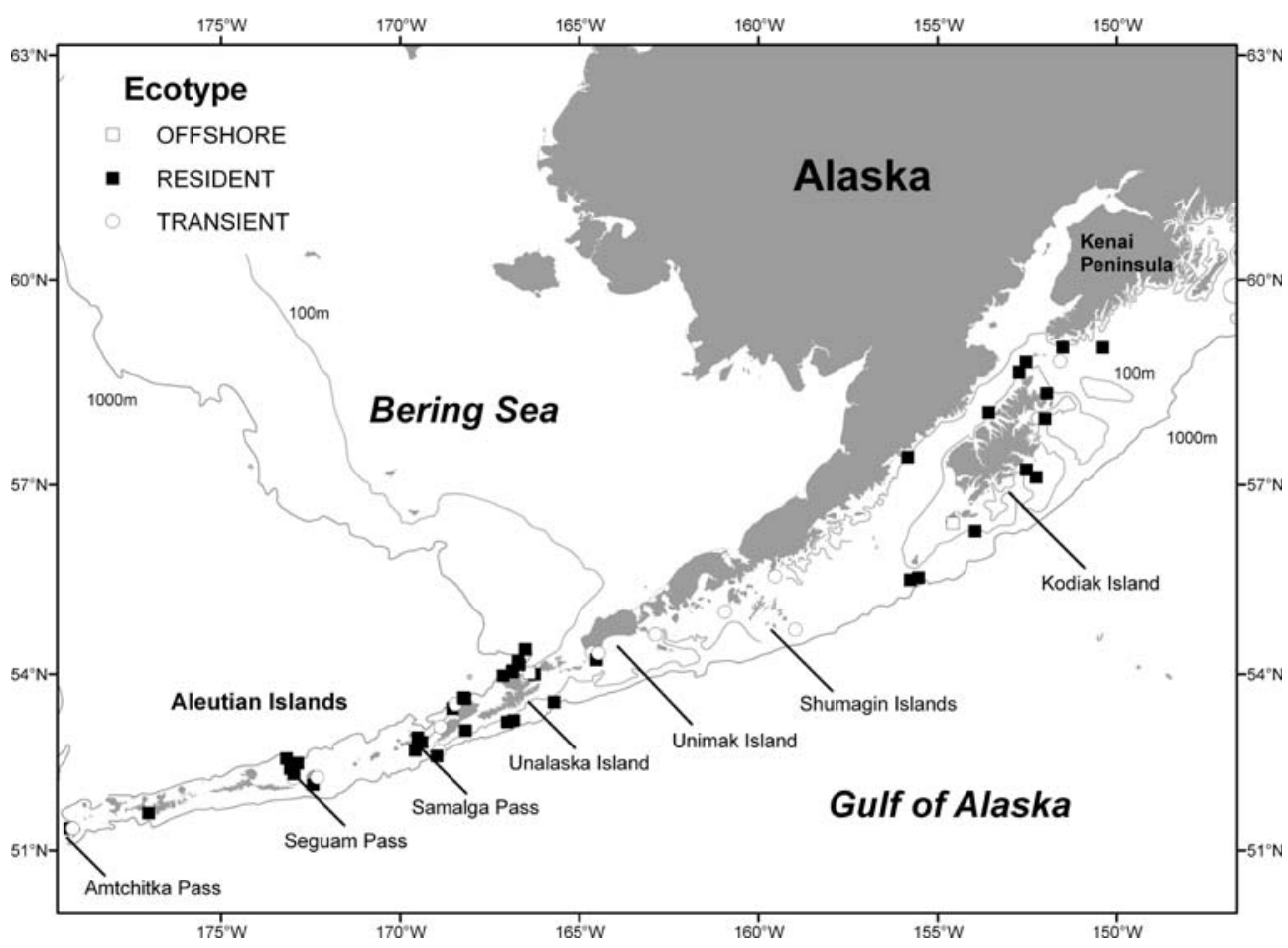

Fig. 2 Distribution in western Alaska and the eastern and central Aleutian Islands 
Table 3 Estimates of abundance of resident $\left(N_{\text {resid }}\right)$, transient $\left(N_{\text {trans }}\right)$ and all ecotypes combined $\left(N_{\text {all }}\right)$, and parameter values for individual models proposed to estimate detection probability

\begin{tabular}{|c|c|c|c|c|c|c|c|c|c|c|c|c|c|c|c|c|}
\hline \multirow[t]{2}{*}{ Model + covariates } & \multirow[t]{2}{*}{$\Delta \mathrm{AIC}$} & \multirow[t]{2}{*}{$w_{\mathrm{i}}$} & \multirow[t]{2}{*}{ \# par } & \multicolumn{6}{|c|}{ Abundance estimates } & \multicolumn{7}{|c|}{ Model parameters } \\
\hline & & & & $\overline{N_{\text {resid }}}$ & $\mathrm{CV}$ & $N_{\text {trans }}$ & $\mathrm{CV}$ & $N_{\text {all }}$ & $\mathrm{CV}$ & $P$ & $b$ & SE & $\theta_{0}$ & SE & $\theta_{\text {size }}$ & SE \\
\hline \multicolumn{17}{|l|}{ Initial group size } \\
\hline $\mathrm{hz}+$ group size covariate & 0.00 & 0.41 & 2 & 934 & 0.49 & 234 & 0.49 & 1,203 & 0.41 & 0.409 & 1.815 & 0.703 & -0.325 & 0.694 & 0.725 & 0.627 \\
\hline hn + group size covariate & 0.12 & 0.39 & 3 & 886 & 0.45 & 181 & 0.41 & 1,092 & 0.37 & 0.491 & - & - & 0.412 & 0.204 & 0.280 & 0.257 \\
\hline $\mathrm{hz}$ & 2.22 & 0.14 & 2 & 1,423 & 0.59 & 201 & 0.49 & 1,650 & 0.53 & 0.393 & 1.359 & 0.547 & 0.049 & 0.598 & - & - \\
\hline $\mathrm{hn}$ & 3.96 & 0.06 & 1 & 1,037 & 0.52 & 146 & 0.41 & 1,202 & 0.45 & 0.539 & - & - & 0.773 & 0.128 & - & - \\
\hline \multicolumn{17}{|c|}{ Post-encounter group size } \\
\hline $\mathrm{hz}+$ group size covariate & 0.00 & 0.45 & 2 & 1,555 & 0.51 & 290 & 0.51 & 1,881 & 0.44 & 0.396 & 1.730 & 0.669 & -0.218 & 0.625 & 0.301 & 0.235 \\
\hline hn + group size covariate & 0.47 & 0.35 & 3 & 1,381 & 0.47 & 224 & 0.44 & 1,630 & 0.40 & 0.493 & - & - & 0.426 & 0.177 & 0.173 & 0.130 \\
\hline $\mathrm{hz}$ & 2.30 & 0.14 & 2 & 2,187 & 0.54 & 252 & 0.53 & 2,466 & 0.49 & 0.393 & 1.359 & 0.547 & 0.049 & 0.598 & - & - \\
\hline $\mathrm{hn}$ & 4.04 & 0.06 & 1 & 1,594 & 0.45 & 183 & 0.45 & 1,797 & 0.40 & 0.539 & - & - & 0.773 & 0.128 & - & - \\
\hline
\end{tabular}

$h z$ hazard rate, $h n$ half normal, $\triangle A I C$ delta Akaike Information Criterion, $w_{\mathrm{i}}$ Akaike weight, \# par number of parameters, $C V$ coefficient of variation, $P$ average detection probability, $b$ shape parameter of the hazard rate model, $S E$ standard error, $\theta$ covariate coefficients $\left(\theta_{0}\right.$ intercept, $\theta_{\text {size }}$ group size covariate)

Table 4 Model-averaged estimates of density and abundance in western Alaska and the Aleutian Islands

\begin{tabular}{|c|c|c|c|c|c|c|c|c|c|c|c|c|c|c|c|c|}
\hline \multirow[t]{3}{*}{ Block } & \multicolumn{8}{|c|}{ Initial group size (IGS) } & \multicolumn{8}{|c|}{ Post-encounter group size (PEGS) } \\
\hline & \multicolumn{4}{|c|}{ Resident } & \multicolumn{4}{|c|}{ Transient } & \multicolumn{4}{|c|}{ Resident } & \multicolumn{4}{|c|}{ Transient } \\
\hline & $D$ & $\mathrm{CV}$ & $N$ & $95 \% \mathrm{CI}$ & $D$ & $\mathrm{CV}$ & $N$ & $95 \% \mathrm{CI}$ & $D$ & $\mathrm{CV}$ & $N$ & $95 \% \mathrm{CI}$ & $D$ & $\mathrm{CV}$ & $N$ & $95 \% \mathrm{CI}$ \\
\hline 1 & - & - & - & - & - & - & - & - & - & - & - & - & - & - & - & - \\
\hline 2 & 0.0153 & 0.53 & 60 & $22-157$ & 0.0066 & 1.25 & 26 & $3-172$ & 0.0283 & 0.53 & 111 & $41-293$ & 0.0069 & 1.25 & 27 & $4-179$ \\
\hline 3 & 0.0139 & 0.87 & 69 & $15-298$ & - & - & - & - & 0.0260 & 0.87 & 128 & $29-555$ & - & - & - & - \\
\hline 4 & 0.0060 & 0.68 & 79 & $23-264$ & - & - & - & - & 0.0112 & 0.79 & 148 & $37-580$ & - & - & - & - \\
\hline 5 & 0.0297 & 1.13 & 290 & 49-1,711 & - & - & - & - & 0.0418 & 0.82 & 407 & $100-1,650$ & - & - & - & - \\
\hline 6 & - & - & - & - & - & - & - & - & - & - & - & - & - & - & - & - \\
\hline 7 & 0.0032 & 2.65 & 32 & $1-546$ & - & - & - & - & 0.0052 & 2.65 & 53 & 3-903 & - & - & - & - \\
\hline 8 & 0.0033 & 1.01 & 47 & $9-244$ & - & - & - & - & 0.0055 & 1.01 & 80 & $15-413$ & - & - & - & - \\
\hline 9 & - & - & - & - & 0.0022 & 1.48 & 12 & $1-101$ & - & - & - & - & 0.0023 & 1.48 & 13 & $1-103$ \\
\hline 10 & - & - & - & - & 0.0013 & 0.66 & 37 & $11-120$ & - & - & - & - & 0.0013 & 0.66 & 38 & $11-124$ \\
\hline 11 & 0.0087 & 1.96 & 130 & $11-1,517$ & 0.0019 & 0.77 & 29 & $7-110$ & 0.0125 & 2.93 & 187 & $9-3,558$ & 0.0021 & 0.77 & 31 & 8-119 \\
\hline 12 & 0.0088 & 0.56 & 177 & $63-493$ & 0.0027 & 0.89 & 54 & $12-243$ & 0.0174 & 0.52 & 351 & $134-916$ & 0.0028 & 0.90 & 57 & $12-254$ \\
\hline 13 & 0.0029 & 0.84 & 46 & 11-192 & - & - & - & - & 0.0041 & 0.84 & 64 & $15-268$ & - & - & - & - \\
\hline 14 & 0.0039 & 1.15 & 61 & $10-372$ & 0.0027 & 0.90 & 42 & 9-188 & 0.0037 & 1.16 & 58 & 9-353 & 0.0055 & 0.90 & 87 & 19-391 \\
\hline 15 & - & - & - & - & - & - & - & - & - & - & - & - & - & - & & - \\
\hline 16 & - & - & - & - & - & - & - & - & - & - & - & - & - & - & & - \\
\hline Total & 0.0046 & 0.52 & 991 & $379-2,585$ & 0.0009 & 0.48 & 200 & $81-488$ & 0.0073 & 0.52 & 1,587 & $608-4,140$ & 0.0012 & 0.51 & 251 & $97-644$ \\
\hline
\end{tabular}

$D$ density (ind $\mathrm{km}^{-2}$ ), $C V(D)$ coefficient of variation of density, $N$ abundance estimate, $95 \% C I 95 \%$ confidence interval

Pass, and the eastern Aleutian Islands. Average density across these areas was 0.002 whales $\mathrm{km}^{-2}$ for both IGS and PEGS (Blocks 9-14, Table 4). Overall densities of transient whales for IGS and PEGS were, respectively, 0.0009 and 0.0012 whales $\mathrm{km}^{-2}$. Abundance was estimated at 200 (IGS) and 251 whales (PEGS) (Table 4).

Small sample size precluded the estimation of abundance of the offshore killer whale ecotype.

\section{Discussion}

Orcinus orca was detected throughout the study area. Resident and transient ecotypes were seen in Amchitka Pass at the far western extreme of the study area, the farthest west that both ecotypes have been documented in US waters. Seguam Pass, as well as the waters around Umnak and Unalaska Islands in the eastern Aleutians, appear to be areas with overall high 
killer whale densities, in addition to relatively frequent sightings around Kodiak Island.

The distinct ecotypes appear to have different distributions. Transient killer whales were seen throughout the study area, but occurred at higher densities from the Shumagin Islands through the eastern Aleutian Islands. Transient killer whales were not encountered between the Shumagin Islands and the eastern side of Kodiak Island in this study, but were observed in the region in previous surveys (e.g., Dahlheim 1997). Resident-type killer whales were particularly abundant around Umnak and Unalaska Islands in the eastern Aleutians, Seguam Pass in the central Aleutians, and on all sides of Kodiak Island. It is suspected that this high density of resident-type whales in the eastern and central Aleutians is at least partially due to the high abundance of prey and high density of fishing boats, as resident killer whales are known to remove fish from long-line gear (Yano and Dahlheim 1995a, b). There was a large gap in the distribution of residents stretching from west of Kodiak Island to the Unimak Pass area. This distributional gap of approximately $800 \mathrm{~km}$ was the same in July and August in all 3 years.

Offshore killer whales were seen twice, once south of Kodiak Island and once northeast of Unalaska Island in the Aleutian Islands. This encounter in the eastern Aleutians represents the most westerly encounter reported with confirmed offshore-type killer whales. Offshore-type killer whales were not previously recognized as a regular component of the ecosystem in the western Gulf of Alaska and Aleutian Islands. However, their detection in multiple years suggests they may be repeatedly found in this region during the summer. Though few sightings were made, the group sizes were large (40 and 60), suggesting that the number of whales may be relatively high. Those two encounters represented more individual whales than the total number of transient-type killer whales that were seen during the surveys (e.g., a total of 40 transient individuals were identified from good-quality photos with distinctive marks in the photo-identification catalogue).

The best models for the detection function selected in the analysis incorporated a covariate for group size. Although the overall estimate of killer whale abundance was relatively similar between models with (MCDS) and without covariate (CDS) (Table 2), the two approaches differed substantially in their ecotypespecific estimates of abundance. There is a clear explanation for this result: Transient-type killer whales were sighted in groups that were on average much smaller than groups of residents (e.g., 3.9 vs. 16 for IGS). Previous studies have shown that group size can have a large influence on the detection of cetaceans at sea (e.g.,
Barlow et al. 2001) and this was found to be the case here. As expected, smaller groups were harder to detect than larger killer whale groups. The estimates of detection probability $(P)$ were made by pooling sightings across ecotype. This pooled detection function was then applied to the sightings of each ecotype to obtain ecotype-specific abundance estimates. When the CDS approach was employed, the effective strip widths were too wide for transients and too narrow for residents. CDS models, therefore, resulted in negative and positive bias for the estimate of transient and resident abundance, respectively. MCDS models corrected this bias because they included a covariate to account for differences in group size. The MCDS approach resulted in a larger estimate of transient abundance and a smaller estimate of resident abundance. For example, even though transient killer whales represented only $6 \%$ of the individuals seen, they represent approximately $17 \%$ of the total killer whale abundance estimate calculated with IGS (Table 2). The encounters with transients are scaled up to abundance because transient killer whales were harder to detect due to their occurrence in smaller groups.

For resident and transient killer whales, the PEGS estimates of abundance were larger than the IGS estimates. There are two factors that account for this difference. First, the observers made the estimates of IGS typically within $\sim 15 \mathrm{~min}$ of the initial close approach to the group of whales. This procedure is consistent with protocols for the estimation of cetacean group sizes during dedicated line-transect surveys. The estimates of PEGS were made after a much longer time was spent observing the group, usually after multiple close approaches while conducting photo-identification and biopsy collection. Greater time gave the observers an opportunity to develop a greater sense of how many whales were in the group (e.g., from recognizing individuals), and in some encounters, the entire group surfaced simultaneously. The result often was an increase in the estimated number of whales after a group was continuously observed.

When large groups of killer whales were encountered, an additional factor may have occasionally led to greater increases in the estimates of PEGS relative to IGS. Large groups of killer whales frequently occurred in several sub-groups. The initial estimate of group size included all sub-groups that were seen initially. However, during the course of photo-identification operations, the ship or small boat often traveled substantial distances, and it was apparent from recognition of individual whales that new sub-groups that were probably not in sight at the time the estimate of IGS was made were sometimes encountered. In some cases, novel 
sub-groups moved into the area where the ship and small boat were operating, also increasing the difference between estimates of IGS and PEGS. The second factor is typically only a problem for resident and offshore ecotypes, as in all of the encounters, transients were in small groups that behaved as a single unit, and were not fragmented into sub-groups.

Factors contributing to differences in estimates of IGS and PEGS have different implications for the estimates of abundance of resident and transient killer whales. The estimates of IGS apparently under-estimated the true size of the group. This suggests that the estimates of PEGS should be more accurate and therefore should be used to obtain abundance for all killer whale ecotypes. However, it is likely, especially for large resident groups, that the estimates of PEGS may not be more accurate because of the inclusion of subgroups of whales that were beyond detection by the observers when they were on-effort. It is likely that these sub-groups would have never been seen if the ship had continued on the transect, as in passing-mode surveys. Inclusion of these sub-groups resulted in estimates of abundance of resident killer whales that were likely positively biased. In fact, the PEGS estimate of abundance was $60 \%$ greater than the IGS estimate in resident-type whales. The estimate of abundance using the IGS data should be more conservative for this ecotype, but all (or even the majority) of the $60 \%$ difference was probably not due to inclusion of additional sub-groups, which is unlikely to have happened on most sightings. For this reason, the best estimate of abundance for resident killer whales lies somewhere between the IGS and PEGS estimates, and the uncertainty may be best reflected by the lower bound of the IGS and the upper bound of the PGES estimates (3794,140). On the other hand, the PEGS estimate of abundance provides the most accurate estimate for transient killer whales, as it corrects for the negative bias in the initial estimate of group size and because counting additional sub-groups was probably not a problem for transients. The PEGS estimate of abundance was $26 \%$ greater than the IGS estimate for transients.

Estimates of abundance presented in the present study assumed that no whales were missed on the track-line $(g[0]=1)$. Failure to meet this assumption is common for some species of marine mammals and causes negative biases in density estimates (Laake 1999; Laake and Borchers 2004). The magnitude of this bias is unknown for killer whales and is likely to be specific to different areas and to the behavior of the whales. However, it is thought to be, on average, larger for transients than residents and perhaps offshore ecotypes. Transient killer whales spend more time under- water than resident whales (Morton 1990) and are less available for detection. In addition, transient killer whales travel in smaller groups (Ford et al. 2000), which also make them more prone to be missed by observers.

These are the first estimates of abundance for transient and resident killer whale ecotypes in the western Gulf of Alaska and the central and eastern Aleutian Islands. Previous studies have used photo-identification catalogues to provide minimum counts for portions of the study area in the present surveys. For example, surveys in 1992 and 1993 from the Kodiak Archipelago to the central and eastern Aleutian Islands and southeastern Bering Sea led to the photoidentification of 254 resident and 35 transient killer whales (Dahlheim 1997). Studies in the Prince William Sound and Kenai Fjords region (including areas both within and beyond the present study area) led to the identification, as of 1998, of 237 resident-type whales and 54 transient-type whales (Matkin et al. 1999a, b). Estimates in this study suggest that killer whale populations in coastal waters south of the Alaska Peninsula are much more abundant than the previously observed in photo-identification counts. However, this difference does not constitute evidence that the population has increased. It can be explained by the greater area surveyed and an estimation method that extrapolates to total abundance.

The population structure between the Gulf of Alaska and the Aleutian Islands is uncertain for both resident- and transient-type killer whales, so it is not clear whether the reported abundances apply to single or multiple populations in each case. Genetic studies of samples obtained during these cruises, and additional surveys, are ongoing to investigate the population structure in these regions.

The overall killer whale density presented here (5.6 whales $1,000 \mathrm{~km}^{-2}$ ) is among the highest in the world and is similar to estimates made for other high-latitude productive waters, such as Norway and Antarctica (Forney and Wade 2006). Waite et al. (2002) estimated $391(95 \% \mathrm{CI}=171-894)$ killer whales of all types in the southeastern Bering Sea using line-transect methods. That estimate applies to an area to the north of the present study area, but indicates that density of killer whales is also high in this area $\left(2.5\right.$ whales $\left.1,000 \mathrm{~km}^{-2}\right)$.

Killer whales are top predators and have the potential to regulate their ecosystem through top-down control. Recent studies have hypothesized that predation by killer whales has caused the decline of sea otters, seals, and Steller sea lions in the Gulf of Alaska, Bering Sea, and the Aleutian Islands with potential cascading effects to lower trophic levels (Estes et al. 1998; 
Springer et al. 2003). Mizroch and Rice (2006), DeMaster et al. (2006), and Wade et al. (2006) suggest that the hypothesis described in Springer et al. (2003) is incorrect. However, Estes et al. (1998) estimated that the decline of sea otters in the Aleutian Islands could be caused by only a small number of killer whales feeding exclusively on sea otters. The abundance estimates presented here reveal a relatively large number of transient-type whales in this region, although it is unknown whether any of these whales prey routinely or exclusively on sea otters. The present estimates can be used in building ecosystem or bioenergetics models to investigate the strength and implications of predatory behavior of both transient and resident killer whales on their ecosystem. Additional data on prey composition in the region are also needed. Herman et al. (2005) used stable isotopes, organochlorine contaminants, and fatty acids to supplement observational studies of killer whale prey preferences.

Williams et al. (2004) used energetic models to calculate the potential number of marine mammal prey that could be killed by an assumed population size of 170 killer whales in the Aleutian Islands, with the further assumptions that the killer whales had a single prey species diet (either sea otters or Steller sea lions) and that the prey population growth rate was zero. The value of 170 was calculated from unpublished survey data from a broad area extending $200 \mathrm{~nm}$ south of the Aleutian Islands (Forney and Brownell 1996), and used preliminary data from the surveys in this paper to assume that $10 \%$ of the killer whales were the transient ecotype. The number of transient-type killer whales used by Williams et al. (2004) is coincidentally similar to this study's estimate of 251 whales for nearshore waters from the Kenai Peninsula to the central Aleutian Islands. Williams et al. (2004) estimated that such a population of transient whales eating only Steller sea lions could account for their decline. Therefore, in theory, transient killer whales could have caused the decline of the Steller sea lion population. However, recent observations of predation by transient whales in this region involve a variety of marine mammal prey, but predominantly gray whales (Eschrichtius robustus) and fur seals (Callorhynus ursinus), with predation on Steller sea lions comprising only a minority of these observations (Matkin et al. 2006; Wade et al. 2006). Clearly, additional studies are needed to better understand the role of killer whales in the Alaska ecosystem and their potential impact on the decline of Steller sea lions. These investigations can be improved using the abundance estimates calculated here, in combination with further observations of prey preferences, movement patterns, and energetic calculations.
Acknowledgments The authors thank Nancy Black, John Brandon, Dave Ellifrit, Jeff Jacobsen, Doug Kinzey, Kery Lodge, Lori Mazzuca, Kim Parsons, Bob Pitman, Michael Richlen, Susan Yin, and Ernesto Vazquez for their dedication and expertise in collecting data. The captains and crew of the Aleutian Mariner and the Coastal Pilot were very cooperative and contributed to the success of this study. Jeff Laake provided guidance and computer code for the data analysis. Kelly Robertson assisted with the DNA sequencing. Reviews by Steve Buckland, Kim Parsons, Glenn VanBlaricom and one anonymous reviewer were greatly appreciated. This study was part of the Ph.D. dissertation of A.N.Z., conducted under the supervision of Dr G. VanBlaricom at the School of Aquatic and Fishery Sciences (SAFS), University of Washington (UW). Funding was provided by the Brazilian Council for Scientific and Technological Development $(\mathrm{CNPq}$, grant\# 200.285/98-0), the National Marine Mammal Laboratory (NMML), and the Washington Cooperative Fish and Wildlife Research Unit, SAFS/UW.

\section{Appendix 1}

Distribution of perpendicular distance $(\mathrm{km})$ of killer whale sightings and fitted detection-probability model (line $=$ mean detection probability, $d o t=$ individual sighting detection probability) used to obtain estimates of abundance of killer whale ecotypes in western Alaska and the eastern and central Aleutian Islands.

\section{References}

Akaike H (1973) Information theory and an extension of the maximum likelihood principle. In: International symposium on information theory, 2nd edn. Akadèemiai Kiadi, Budapest, pp 267-281

Baird RW (2000) The killer whale foraging specializations and group hunting. In: Mann J, Connor RC, Tyack PL, Whitehead $\mathrm{H}$ (eds) Cetacean societies. Field studies of dolphins and whales. The University of Chicago Press, Chicago, pp 127-153

Baird RW, Stacey PJ (1988) Variation in saddle patch pigmentation in populations of killer whales (Orcinus orca) from British Columbia, Alaska, and Washington State. Can J Zool 66:2582-2585

Barlow J (1995) The abundance of cetaceans in California waters. Part II: ship surveys in summer and fall of 1991. Fish Bull 93:1-14

Barlow J, Gerrodette T, Forcada J (2001) Factors affecting perpendicular sighting distances on shipboard line-transect surveys for cetaceans. J Cetacean Res Manage 3:201-212

Barrett-Lennard LG (2000) Population structure and mating patterns of killer whales (Orcinus orca) as revealed by DNA analysis. Ph.D. Dissertation, University of British Columbia, Vancouver, British Columbia

Barrett-Lennard LG, Ford JKB, Heise KA (1996) The mixed blessing of echolocation: differences in sonar use by fish-eating and mammal-eating killer whales. Anim Behav 51:553565

Bigg MA, Ellis GM, Ford JKB, Balcomb KC (1987) Killer whales-a study of their identification, genealogy and natural history in British Columbia and Washington State. Phanton, Nanaimo, British Columbia 
Bigg MA, Olesiuk PF, Ellis GM, Ford JKB, Balcomb KC (1990) Social organization and genealogy of resident killer whales (Orcinus orca) in the coastal waters of British Columbia and Washington State. Rep Int Whal Comm (Special Issue) 12:383-405

Black NA, Schulman-Janiger A, Ternullo RL, Guerrero-Ruiz M (1997) Killer whales of California and western Mexico: a catalog of photo-identified individuals. NOAA Technical Memo NOAA-TM-NMFS-247. US Department of Commerce, La Jolla

Braham HW, Dahlheim ME (1982) Killer whales in Alaska documented in the platform of opportunity program. Rep Int Whal Comm 32:643-646

Branch TA, Butterworth DS (2001) Estimates of abundance south of $60^{\circ} \mathrm{S}$ for cetacean species sighted frequently on the $1978 / 79$ to $1997 / 98$ IWC/IDCR-SOWER sighting surveys. J Cetacean Res Manage 3:251-270

Buckland ST, Anderson DR, Burnham KP, Laake JL, Borchers DL, Thomas L (2001) Introduction to distance sampling. Estimating abundance of biological populations. Oxford University Press, New York

Buckland ST, Anderson DR, Burnham KP, Laake JL, Borchers DL, Thomas L (eds) (2004) Advanced distance sampling. Estimating abundance of biological populations. Oxford University Press, New York

Burnham KP, Anderson DR (2002) Model selection and multimodel inference. Springer, Berlin Heidelberg New York

Dahlheim ME (1997) A photographic catalog of killer whales (Orcinus orca) from the central Gulf of Alaska to the southeastern Bering Sea. NOAA Technical Report

Dahlheim ME, Heyning JE (1998) Killer whale Orcinus orca (Linnaeus, 1758). In: Ridgway S, Reynolds J (eds) Handbook of marine mammals, vol. 6. Academic, San Diego, pp 281-322

Dahlheim ME, Waite JM (1993) Abundance and distribution of killer whales (Orcinus orca) in Alaska, 1992. Annual Report MMPA Assessment Program, Office of Protected Resources, NMFS, NOAA, Silver Spring

Dahlheim ME, Leatherwood S, Perrin WF (1982) Distribution of killer whales in the warm temperate and tropical eastern Pacific. Rep Int Whal Comm 32:647-653

Dahlheim ME, Ellifrit DK, Swenson JD (1997) Killer whales of southeast Alaska. A catalogue of photo-identified individuals. Day Moon, Seattle

DeMaster DP, Trites AW, Clapham P, Mizroch S, Wade PR, Small RJ (2006) The sequential megafaunal collapse hypothesis: testing with existing data. Prog Oceanogr PICES 68:329-342

Estes JA, Tinker MT, Williams TM, Doak DF (1998) Killer whale predation on sea otters linking oceanic and nearshore ecosystems. Science 282:473-476

Ford JKB (1990) Vocal traditions among resident killer whales (Orcinus orca) in coastal waters of British Columbia. Can J Zool 69:1454-1483

Ford JKB, Ellis GM (1999) Transients: mammal-hunting killer whales. University of British Columbia Press, Vancouver, $\mathrm{BC}$

Ford JKB, Ellis GM, Barret-Lennard LG, Morton AB, Palm RS, Balcomb KC (1998) Dietary specialization in two sympatric populations of killer whales (Orcinius orca) in coastal British Columbia and adjacent waters. Can J Zool 76:1456-1471

Ford JKB, Ellis GM, Balcomb KC (2000) Killer whales: the natural history and genealogy of Orcinus orca in British Columbia and Washington State. 2nd edn. UBC, Vancouver, Canada

Forney KA, Brownell RL Jr (1996) Preliminary report of the 1994 Aleutian Island marine mammal survey. In: Paper SC/
48/O11 presented to the international whaling commission scientific committee, pp. 1-15

Forney KA, Wade PR (2006) World-wide abundance and density of killer whales. In: Estes J (ed) Whales, whaling and ecosystems. University of California Press, Berkeley (in press)

Forney KA, Barlow J, Carretta JV (1995) The abundance of cetaceans in California waters. Part II aerial surveys in winter and spring of 1991 and 1992. Fish Bull 93:15-26

Hammond PS (1984) Abundance of killer whales in Antarctic Areas II, III, IV, and V. Rep Int Whal Comm 34:543-548

Herman DP, Burrows DG, Wade PR, Durban JW, Matkin CO, LeDuc RG, Barrett-Lennard LG, Krahn MM (2005) Feeding ecology of eastern North Pacific killer whales from fatty acid, stable isotope and organochlorine analyses of blubber biopsies. Mar Ecol Prog Ser 302:275-291

Hoelzel AR, Dover GA (1991) Genetic differentiation between sympatric killer whale populations. J Hered 66:191-195

Hoelzel AR, Dahlheim ME, Stern SJ (1998) Low genetic variation among killer whales (Orcinus orca) in the eastern North Pacific, and differentiation between sympatric killer whale populations. J Hered 89:121-128

Hoelzel AR, Natoli A, Dahlheim ME, Olavarria C, Baird RW, Black N (2002) Low worldwide genetic diversity in the killer whale (Orcinus orca): implications for demographic history. Proc R Soc Lond B 269:1467-1473

Innes S, Heide-Jørgensen MP, Laake JL, Laidre KL, Cleator HJ, Richard P, Stewart REA (2002) Survey of belugas and narwhals in the Canadian High Arctic in 1996. NAMMCO Scientific Publ 4:169-190

Jones IM (2006) A northeast Pacific offshore killer whale (Orcinus orca) feeding on a Pacific halibut (Hippoglossus stenolepis). Mar Mammal Sci 22:198-200

Laake J (1999) Distance sampling with independent observers: reducing bias from heterogeneity by weakening the conditional independence assumption. In: Garner GW, Amstrup SC, Laake JL, Manly BJF, McDonald LL, Robertson DG (eds) Marine mammal survey and assessment methods. AA Balkema, Rotterdam, pp 137-148

Laake JL, Borchers DL (2004) Methods for incomplete detection at distance zero. In: Buckland ST, Anderson DR, Burnham KP, Laake JL, Borchers DL, Thomas L (eds) Advanced distance sampling. Estimating abundance of biological populations. Oxford University Press, Oxford, pp 108-188

Lerczak JA, Hobbs R (1998) Calculating sighting distances from angular readings during shipboard, aerial and shore-based marine mammal surveys. Mar Mammal Sci 14:590-599 (Errata 1998 Mar Mammal Sci 14:903)

Loughlin TR, Sterling JT, Merrick R, Sease JL, York AE (2003) Diving behavior of immature Steller sea lions (Eumetopias jubatus). Fish Bull 101:566-582

Lowry LF, Burns JJ, Nelson RR (1987) Polar bear, Ursus maritimus, predation of belugas, Delphinapterus leucas, in the Bering and Chukchi Seas. Can Field Nat 101:141-146

Marques FFC, Buckland ST (2003) Incorporating covariates into standard line transect analyses. Biometrics 59:924-935

Matkin CO, Saulitis EL (1994) Killer whale (Orcinus orca) biology and management in Alaska. Contract report to the Marine Mammal Commission. Contract number T75135023

Matkin CO, Ellis GM, Dahlheim ME, Zeh J (1994) Status of killer whales in Prince William Sound (1985-1992). In: Loughlin $\mathrm{T}$ (ed) Impacts of the EXXON Valdez oil spill on marine mammals. Academic, San Diego, pp 141-162

Matkin CO, Ellis GM, Olesiuk PF, Saulitis E (1999a) Association patterns and inferred genealogies of resident killer whales, Orcinus orca, in Prince William Sound, Alaska. Fish Bull 97:900-919 
Matkin CO, Ellis GM, Saulitis E, Barrett-Lennard L, Matkin D (1999b) Killer whales of southern Alaska. North Gulf Oceanic Society, Homer, Alaska

Matkin CO, Barret-Lennard LG, Ellifrit D, Yurk H, Trites AW (2006) Ecotypic variation and predatory behavior of killer whales (Orcinus orca) in the eastern Aleutian Islands, Alaska. Fish Bull (in press)

Merrick RL, Loughlin TR (1997) Foraging behavior of adult female and young-of-the-year Steller sea lions in Alaskan waters. Can J Zool 75:776-786

Mizroch SA, Rice DW (2006) Have North Pacific killer whales switched prey species in response to depletion of the great whale populations? Mar Ecol Prog Ser 310:235-246

Morton AB (1990) A quantitative comparison of the behavior of resident and transient forms of killer whale off the central British Columbia coast. Rep Int Whal Comm (Special Issue) 12:245-248

National Research Council (2003) Decline of the Steller sea lion in Alaskan waters. National Academy Press, Washington

Olesiuk PF, Bigg MA, Ellis GM (1990) Life history and population dynamics of resident killer whales (Orcinus orca) in the coastal waters of British Columbia and Washington State. Rep Int Whal Comm (Special Issue) 12:209-243

Rosel PE, Dizon AE, Heyning JE (1994) Genetic analysis of sympatric morphotypes of common dolphins (genus Delphinus). Mar Biol 119:159-167

Saulitis E, Matkin C, Barrett-Lennard L, Heise K, Ellis G (2000) Foraging strategies of sympatric killer whale (Orcinus orca) populations in Prince William Sound, Alaska. Mar Mammal Sci 16:94-109

Sigurjónsson J, Gunnlaugsson T, Payne M (1989) NASS-87: shipboard sighting surveys in Icelandic and adjacent waters June-July 1987. Rep Int Whal Comm 39:395-409
Springer AM, Estes JA, van Vliet GB, Williams TM, Doak DF, Danner EM, Forney KA, Pfister B (2003) Sequential megafaunal collapse in the North Pacific Ocean: an ongoing legacy of industrial whaling? Proc Natl Acad Sci USA 100:12223-12228

Wade PR, Gerrodette T (1993) Estimates of cetacean abundance and distribution in the eastern tropical Pacific. Rep Int Whal Comm 43:477-493

Wade PR, Barrett-Lennard LG, Black N, Brownell B Jr, Burkanov V, Burdin A, Calambokidis J, Cerchio S, Dahlheim M, Ford J, Friday N, Fritz L, Jacobsen J, Loughlin T, Lowry M, Matkin C, Matkin D, Mehta A, Mizroch S, Muto M, Rice D, Siniff D, Small R, Steiger G, Straley J, VanBlaricom G, Clapham P (2006) Marine mammal abundance, biomass, and trends in the North Pacific - a re-examination of evidence for sequential megafauna collapse. Mar Mammal Sci (in press)

Waite JM, Friday NA, Moore SE (2002) Killer whale (Orcinus orca) distribution and abundance in the central and southeastern Bering Sea, July 1999 and June 2000. Mar Mammal Sci 18:779-786

Williams TM, Estes JA, Doak DF, Springer A (2004) Killer appetites: assessing the role of predators in ecological communities. Ecology 85:3373-3384

Yano K, Dahlheim ME (1995a) Behavior of killer whales Orcinus orca during longline fishery interactions in the southeastern Bering Sea and adjacent waters. Fish Sci 61:584-589

Yano K, Dahlheim ME (1995b) Killer whale, Orcinus orca, depredation on longline catches of bottom fish in the southeastern Bering Sea and adjacent waters. Fish Bull 93:355-372 


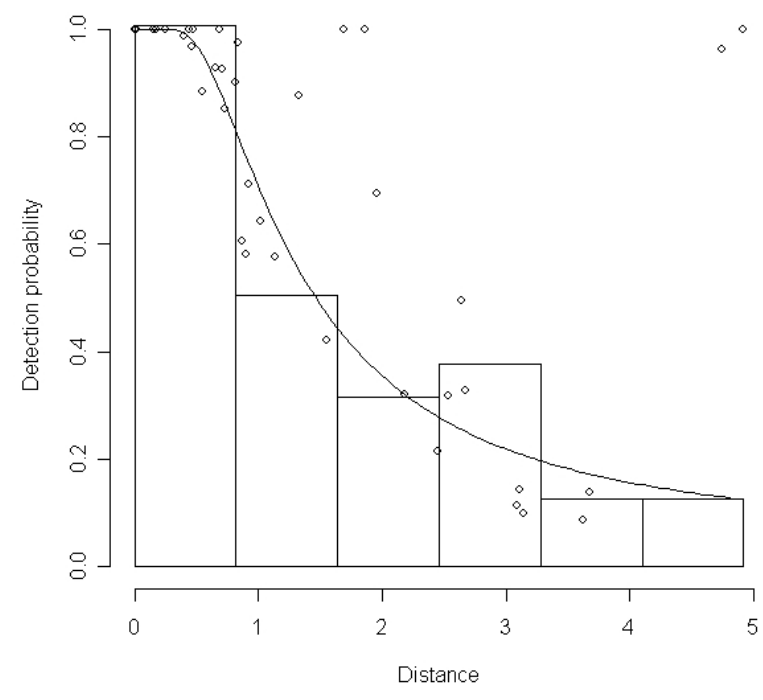

Hazard rate + size covariate

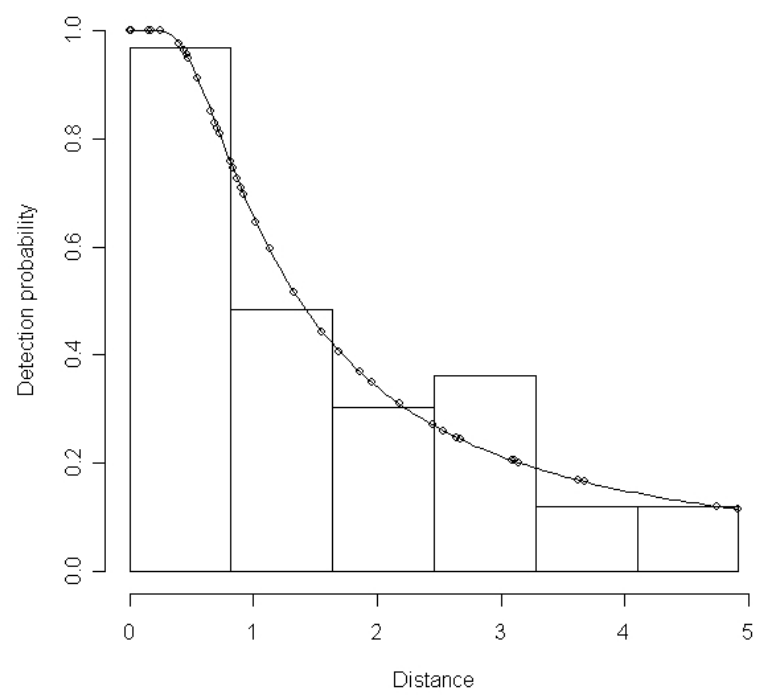

Hazard rate

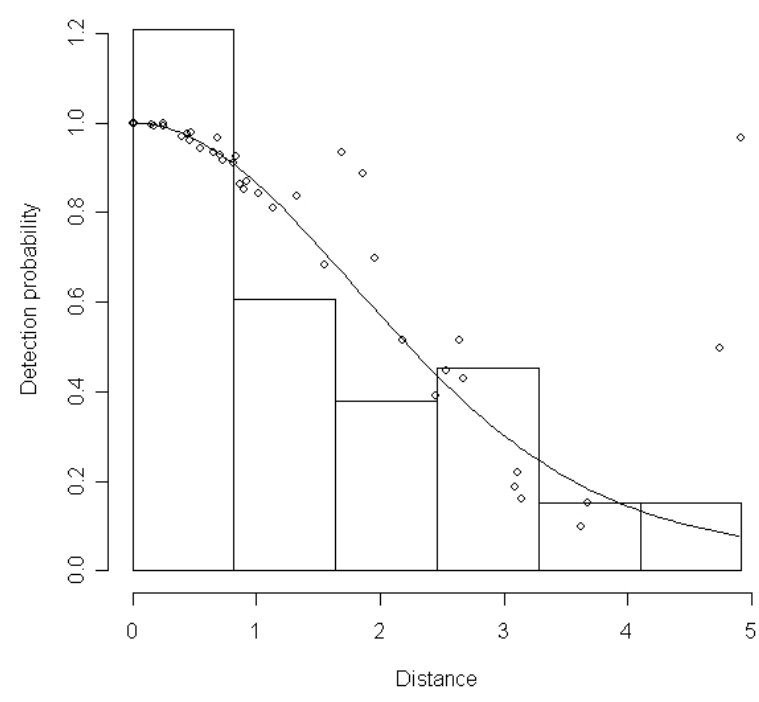

Half normal + size covariate

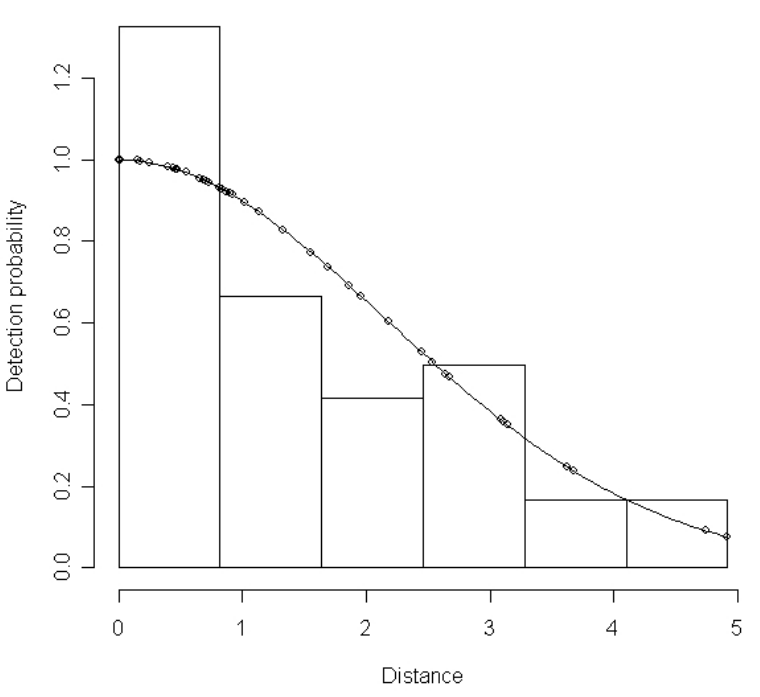

Half normal 